\title{
Virulence of Puccinia striiformis f. sp. tritici in Khuzestan Province of Iran
}

\author{
S. Elyasi-Gomari ${ }^{\star \star}$ and V. P. Petrenkova ${ }^{2}$ \\ ${ }^{1}$ Department of Plant Protection, Faculty of Agriculture, Shoushtar Branch, \\ Islamic Azad University, Khuzestan, Iran. \\ ${ }^{2}$ National Centre for Plant Genetic Resources of Ukraine, Moskovskiy Prospect, \\ 142, Kharkiv, 61060, Ukraine.
}

Research Article

Received $4^{\text {th }}$ July 2011

Accepted $24^{\text {th }}$ July 2011

Online Ready $23^{\text {rd }}$ August 2011

\section{ABSTRACT}

Yellow rust caused by Puccinia striiformis f. sp. tritici is undoubtedly, the most important fungal disease of wheat especially in Central and Western Asia causes significant annual yield losses. To investigate the population structure of the pathogen, isolates were collected from four regions and tested on 26 differential genotypes with known resistance genes in greenhouse and field conditions on the territory of Khuzestan province in Iran during 2009 2010. According to the results of race determination, races 4E14, 4E15, 6E128, 6E148, $6 \mathrm{E} 142,6 \mathrm{E} 130,6 \mathrm{E} 158,134 \mathrm{E} 4$ and 166E232 were common in all locations during the course of this study. Isolates with virulence on lines with yellow rust resistance gene Yr2, Yr6, Yr7, Yr7+, Yr6+, Yr9, Yr17, Yr18, Yr25 and YrA represented the most frequent phenotypes. Virulence to Yr1, Yr3V, Yr4, Yr5, Yr10 and YrSU was not found in any of the tested isolates. At the adult plant stage, virulence on wheat genotypes Heines Kolben, Kalyansona, Lee, Avocet R, Federation* 4/Kavkaz, TP1295 and Nord desprez was common during the period of investigation. The frequency of virulence factors in the yellow rust population on the differential genotypes were above 91\% for the resistance genes Yr2,Yr6, Yr7, Yr2, Yr6+, Yr18, YrA, Yr2, Yr17, Yr25 and YrA however, virulence frequencies for Yr7+ and Yr8 were less than 10\%. Frequency of virulence factors was low for Yr 2+, Yr7+, Yr8, Yr3N and YrSd.

Keywords: Triticum aestivum; resistance genes; Puccinia striiformis; 


\section{INTRODUCTION}

With more than 7000 species, rust fungi (Basidiomycota, Uredinales) are the largest group of obligate plant pathogens known to date (Aime, 2006). Among them, there are disease agents that severely affect field crops, vegetables, ornamentals, fruit, and forest trees (Agrios, 1997). Wheat rusts, for example, have influenced the course of early civilization by destroying a major source of food (Wiese, 1987) and are still most destructive pathogens in all provinces of Iran where, in 1993, have caused more than 1 million tons yield loss (Okhovat, 1999). Stripe rust is a micro cyclic rust disease causing important economic losses on some important members of Graminae family (Kavak, 2009). Stripe rust was dominant disease in Central Asian countries in the late 1990s and early 2000s, accounting for yield losses of 20-40\% in 1999 and 2000 (Morgounov et al., 2004). During the last decades, several yellow rust epidemics in most of the wheat-growing areas of Iran caused over $30 \%$ crop loss and estimated grain losses were 1.5 and 1.5 million ton in 1993 and 1995, respectively (Torabi et al., 1995). Stripe rust can cause $100 \%$ yield loss if infection occurs very early and the disease continues to develop during the growing season provided the cultivars are susceptible (Afzal et al., 2007). In Iran, epidemics of cereal rusts occur every 3 or 4 years and frequent stripe rust epidemics have been reported in Iran (Esfandiari, 1947; Khazra et al., 1974; Bamdadian, 1984). The annual yield losses due to wheat yellow rust have been estimated up to $8-75 \%$ (Elahinia, 2000).

Bamdadian (1984) estimated that overall losses in these years may be as high as 30 to $40 \%$. In 1994, an estimated 15\% (1.5 million tonnes) of the nation's wheat yield loss in Iran was caused by stripe rust (Torabi et al., 1995), particularly where the susceptible variety Very was grown over large areas. Wan et al., (2004) reported that, in the 2001-2002 growing season, a widespread stripe rust epidemic affected about 6.6 million hectares of wheat in China. Johnson et al., (1972) suggested a differential set and a new system for pathotype nomenclature based on the use of binary codes. Pathogenic changes have been a significant factor in the recurrent $P$. striiformis epidemics in the Middle East. In Iran, yellow rust has been observed annually since 1984 and the disease has spread to all wheatgrowing areas. Under irrigated conditions and in the high rainfall areas in northern Iran, the severity of infection reached up to $80 \%$ on susceptible cultivars (Elahinia, 1989). The use of genetic resistance in wheat is the most economic way of controlling the disease (Röbbelen and Sharp, 1978; Line and Chen, 1995; Elyasi-Gomari and Lesovaya, 2009). In general, there are two mechanisms of resistance to stripe rust: seedling resistance, which can be expressed in all stages of plant development, and adult plant resistance, which expresses in adult stages. Several researchers have reported rust resistance in different wheat genotypes in Iran (Torabi et al., 1995; Khalilzadeh, 2008). However, their studies were based only on vertical resistance. Little research has been reported on screening of wheat lines for slow rusting. Seven pathotypes, viz. 6E0, 20E148, 38E134, 166E150, 6E20, 134E150 and 230E150 were reported in Iran between 1996 and 1997 (Torabi et al., 1998). Elahinia (2000) reported that the races identified in 1999, such as 230E150 and 230E134, have wider spectra of virulence on resistant genotypes than races collected in 1994. Afshari et al. (2006) reported seven pathotypes including five pathotypes of yellow rust, 14E176A+, 134E142A+, 6E210A+, 4E128A- and 64E146A+ in Iran between 2003 and 2004 and virulence wasn't detected for plants with genes $\mathrm{Yr} 1, \mathrm{Yr} 4, \mathrm{Yr} 5$ and $\mathrm{Yr} 10$ but virulence on plants with genes Yr2, Yr6, Yr7, Yr9, Yr22, Yr23 and YrA was common until 2005. The objectives of this study were to (i) Identify the frequencies of wheat strip rust races Khuzestan Province of Iran in 2009 and 2010 and (ii) determine the virulence factors of the wheat yellow rust pathogen. 


\section{MATERIALS AND METHODS}

For determination of the virulence spectra of the isolates, differential host genotypes with known seedling resistance genes were used. These include entries from the European and world sets. A set of the world and European wheat yellow rust differentials as proposed by Johnson et al. (Johnson et al., 1972) was used for this study (Table 1).

Table 1. Infection types of Puccinia strifformis f. sp. tritici isolates on wheat

\begin{tabular}{lc}
\hline Description of infection & $\begin{array}{c}\text { Index } \\
\text { value }\end{array}$ \\
\hline Immune/no symptom & 0 \\
Hypersensitive flecks without uredia & 1 \\
Necrotic/Chlorotic flecks without uredia & 2 \\
Necrotic/Chlorotic stripes without uredia & 3 \\
Necrotic/Chlorotic stripes with trace uredia & 4 \\
Necrotic/Chlorotic stripes with light uredia & 5 \\
Necrotic/Chlorotic stripes with intermediate uredia & 6 \\
Necrotic/Chlorotic stripes with moderate uredia & 7 \\
Chlorotic stripes with abundant uredia & 8 \\
Abundant uredia without necrosis/chlorosis & 9 \\
\hline
\end{tabular}

Ten additional cultivars-lines, Anza, Avocet 'R', Avocet 'S', Kalyansona, Federation 4/Kavkaz, Triticum Spelta Album, TP 981, TP 1295, Trident, and Bolani, were added, making a total of 26 cultivars-lines (Table 2). Under field conditions, spreader rows served as a source of inoculum. Primary infection by airborne rust spores developed rapidly on the mixture of susceptible cultivars, and then subsequent spread of urediniospores occurred naturally on the surrounding plots of the differential cultivars. The trap nursery was evaluated at all testing sites for two years. Severity of infection (0 to 100\%) and reaction type (R, S) as designated by Peterson et al. (1948) were assessed at heading stage (Zadoks et al., 1974). The frequency of infection of each genotype was calculated as the relative percent frequency of infection of susceptible lines over 2 years at all the testing sites in Khuzestan province of Iran.

Collection of stripe rust samples was carried out in the 2009 and 2010 growing season Khuzestan province of Iran. Uredospores from a single pustule were isolated and propagated on the susceptible cultivar Bolani for each collection. For inoculation, uredospores were mixed with talcum powder in the ratio 1:3, and sprayed on to seedlings using a fine mist atomizer. The objective of using a mixture of talcum powder and the uredospores was to help settling spores in a uniform manner on seedling leaves. After each inoculation, the spraying equipment was thoroughly washed in water and put in an oven with $60^{\circ} \mathrm{C}$ for 12 hours to avoid contamination when consecutive inoculations with different pathotypes were carried out. $P$. striiformis, inoculation rooms consisted of a trolley with a base tray containing $2 \mathrm{~cm}$ of tap water. After inoculation, seedlings were placed on the trolleys and covered with plastic hoods. Trolleys were placed in an incubation room at $10^{\circ} \mathrm{C}$ where the differential temperatures between the water and room temperature resulted in dew formation. Following incubation, plants were moved to greenhouse chambers capable of being set to a range of temperatures. The temperatures used $18^{\circ} \mathrm{C}$ with $16 \mathrm{~h} / 8 \mathrm{~h}$ day/night. Virulence surveys of cereal rust fungi have traditionally used differential host genotypes that express resistance in the primary leaves of seedling plants (Kolmar, 1997). 
Table 2. Host differential genotypes for Puccinia striiformis

\begin{tabular}{lc}
\hline Wheat differential & Resistance genes \\
genotypes-cultivars & \\
\hline World differential set & Yr1 \\
Chinese 166 & Yr7 \\
Lee & Yr2,Yr6 \\
Heines Kolben & Yr3V \\
Vilmorin 23 & Yr10 \\
Moro & YrSd \\
Strubes Dickopf & YrSu \\
Suwon 92×Omar & Yr2, Yr9+ \\
Clement & \\
European differential set & Yr4 \\
Hybrid 46 & Yr7+ \\
Reichersberg 42 & Yr2+, Yr6 \\
Heines Peko & Yr3N \\
Nord Desprez & Yr8 \\
Compair & Yr32+ \\
Carstens V & YrSp \\
Spaldings prolific & Yr2+ \\
Heines VII & \\
Supplemental differential set & Yr18, YrA \\
Anza & Yr9 \\
Federation*4/Kavkaz & YrA \\
Avocet ' R' & - \\
Avocet ' S ' & Yr2 \\
Kalyansona & Yr5 \\
Triticum Spelta Album & - \\
Bolani & Yr25 \\
TP 1295 & Yr17 \\
Trident & - \\
TP 981 &
\end{tabular}

The infection types (IT) of $P$. striiformis on the wheat genotypes were scored using a 0 to 9 scale 15-18 days after inoculation as described by MacNeal et al., (1971) and Stubbs (1988). They were classified into resistant (0-5) and susceptible (6-9) types. Infection types (ITs) 7 to 9 were regarded as virulent (susceptible) and less than seven was avirulent.. For $P$. striiformis the pathotype nomenclature of Johnson et al. (1972) was used. Uredospores of the pathogen were stored in aluminum foil packets placed in liquid nitrogen $\left(-196^{\circ} \mathrm{C}\right)$ for further investigations.

\section{RESULTS AND DISCUSSION}

For a period of two consecutive years, leaf samples were collected from durum and bread wheat cultivars, as well as from differential cultivars grown under field conditions in Khuzestan province of Iran. Single-uredinial isolates of $P$. striiformis were characterized for physiologic races. The results obtained from this study showed that there were identified 27 physiologic races during the course of this study (Table 3 ). 
Table 3. Yellow rust races identified in Khuzestan Province of Iran from 2009 to 2010

\begin{tabular}{|c|c|c|c|c|c|c|c|c|}
\hline \multirow[b]{2}{*}{$\begin{array}{l}\text { Physiologic } \\
\text { race }\end{array}$} & \multicolumn{8}{|c|}{ Khuzestan Province } \\
\hline & Ahvaz & Dezful & Shushtar & Ize & MasjdSleman & Abadan & Mahshahr & Behbehan \\
\hline 4E15 & + & + & + & + & + & + & & \\
\hline 4E14 & + & + & + & & + & + & + & \\
\hline 6E0 & + & + & + & + & + & + & + & + \\
\hline 6E2 & + & & + & & & & & + \\
\hline $6 \mathrm{E} 4$ & & & + & & & & + & \\
\hline 6E6 & + & + & & & & & & \\
\hline 6E22 & + & & & & & & & + \\
\hline 6E44 & & + & + & & & & & \\
\hline 6E78 & & & + & & + & & & \\
\hline $6 \mathrm{E} 128$ & + & + & + & + & & & & + \\
\hline $6 \mathrm{E} 130$ & + & + & & + & + & & & + \\
\hline 6E134 & + & + & + & & & & & + \\
\hline 6E138 & & & + & & & & & + \\
\hline 6E142 & + & + & & & + & & + & + \\
\hline $6 \mathrm{E} 148$ & + & + & + & & + & & + & + \\
\hline 6E150 & + & + & + & & + & & + & + \\
\hline $6 E 158$ & + & + & + & & + & & & \\
\hline 6E174 & & + & + & & + & & & \\
\hline 38E66 & + & & + & & + & & & + \\
\hline 64E216 & & & + & & & & & + \\
\hline $70 E 0$ & & & + & & & & & + \\
\hline 70E132 & & & + & & & & & + \\
\hline 124E160 & + & + & + & & & & & \\
\hline 132E48 & + & + & & & & & & \\
\hline 134E150 & + & + & + & & & & & + \\
\hline 166E134 & & & + & & & & & + \\
\hline 166E232 & + & + & & & + & & & + \\
\hline
\end{tabular}


The composition of physiologic races found in 2009 and 2010 differed greatly on the world differential set but not as much on the European differential set. All $P$. Striiformis physiologic races identified in this study differed in their occurrence during a two years period. On the world differential set, the differential genes, YrSU and Yrg+ in Suwon92 $\times$ Omar and Clement, respectively, allowed clear discrimination among the races in Khuzestan province of Iran. Virulence for these genes occurred in 2010 but not in 2009 (Table 3).

In the case of the European differential genotypes, virulence for the resistance genes $Y r 7+$, $\mathrm{Yr6}+, \mathrm{Yr2}+$, and $\mathrm{Yr} 8$, and avirulence for $\mathrm{Yr4}+, \mathrm{YrCV}$, and $\mathrm{YrSP}$, were observed in the 2009 and 2010 P. striiformis populations. The world differential did not allow distinction between four races 4E14, 4E15,6E0, 6E128 in 2009 and two races 6E44 and 6E148 in 2010, whereas European differentials showed differential reactions on $Y r 7+, Y r 6+$, and $Y r 8$ resistance genes (Table 4) for these races. Thus, the use of both differentials allowed for better discrimination between yellow rust races. Four distinct physiologic races were identified in 2010 compared with seven races in 2009. Races identified in 2010, such as $4 \mathrm{E} 15,6 \mathrm{E} 44$ and 70E32, have wider spectra of virulence for yellow rust resistance genes than the races identified in 2009, such as 4E14, 4E15, and 6E0. In 2010, virulence for the YrSu resistance gene was the major virulence change recorded in Khuzestan compared with the results from 2009. Physiologic race 6E6 was first observed in the region in 1972 (Bamdadian, 1972). Significant changes in race composition were identified using the world and European differential sets (Table 4).

In this study, 6E6 have virulence on 10 known genes in the host plants and this race is virulent for $Y r 2, Y r 6, Y r 7, Y r 2, Y r 6+, 7+, 17,18$ and $Y r A$. 6E6 and is present in many wheat cultivars that are still cultivated over relatively large areas in Iran. Race 6E148 and 6E158 were the second most frequent race in Iran and was found for five locations in years, whereas 6E142, 6E130 and 6E128 were identified for four locations, respectively (Table 3). Races $6 \mathrm{E} 0$ and 4E15 are among the most virulent races identified and could be among the $P$. striiformis races that contributed most to yellow rust epidemics in this region. This race has a broad virulence spectrum and was recovered during four consecutive years (1994 to 1997) in Iran (Nazari, 1998; Torabi et al., 1995). In Iran, only three physiologic races 6E0, 6E2, 6E4 occurred for four consecutive years in the early 1990's and races 6E134 and 6E150 were also found only once in 1997 and 1996, respectively (Nazari, 1998).

Among the races that occurred only once during the period of the study, races $4 \mathrm{E} 14,4 \mathrm{E} 15$ 6E22, 6E128, 6E130, 6E148 6E134, 6E142, 6E158, 134E150, and 166E232 were common in all locations and observed during the course of the study could be attributed to changes in bread wheat varieties being cultivated over large areas, to the extension of resistant durum wheat varieties to irrigated areas of Iran, to monoculture of limited numbers of bread wheat varieties, or simply to limited sampling locations. According to the results, virulence on plants with gene/s Yr2, Yr6, Yr7, Yr9, Yr3N, Yr2, Yr6+, Yr2, Yr9+ and YrA was detected (Table 4). The majority of isolates with high frequency showed virulence on plants with Yr2, Yr6, Yr7, Yr9, Yr25 and YrA genes. No virulence was detected on plants with Yr1, Yr3V, Yr4, Yr5, Yr10 and YrSU genes.

The presence of virulence on plants with the genes $Y r 3 N, Y r 8, Y r 32+, Y r S D$ and $Y r S P$ in the seedling test and absent in the four regions at the adult plant stage, could be due to the low frequency of virulence for those genes under field conditions. Special leaf collections were made from selected differential genotypes associated with resistance genes, some of which are being exploited in many wheat varieties, and from land race bread wheat cultivars. 
Table 4. Reaction of host differential genotypes to Khuzestan yellow rust physiologic races in 2009 and 2010

\begin{tabular}{|c|c|c|c|c|c|c|c|c|c|c|c|c|}
\hline \multirow{3}{*}{$\begin{array}{l}\text { Differential } \\
\text { genotype }\end{array}$} & \multirow[t]{3}{*}{ Yr gene* } & \multicolumn{11}{|c|}{ Physiologic races ${ }^{* *}$ and reaction ${ }^{*}$ of differential sets } \\
\hline & & \multicolumn{4}{|c|}{2009} & \multicolumn{7}{|c|}{2010} \\
\hline & & 4E14 & 4E15 & 6E0 & 134E150 & 6E6 & 6E148 & 6E158 & 6E130 & 70E0 & 70E132 & 166E232 \\
\hline \multicolumn{13}{|c|}{ World differential set } \\
\hline Chinese 166 & Yr1 & 1 & 0 & 0 & 0 & 0 & 1 & 1 & 1 & 0 & 0 & 1 \\
\hline Lee & Yr7 & 8 & 6 & 6 & 0 & 7 & 7 & 7 & 8 & 8 & 9 & 0 \\
\hline Heines Kolben & Yr2, Yr6 & 8 & 7 & 9 & 8 & 7 & 8 & 8 & 8 & 7 & 8 & 8 \\
\hline Vilmorin 23 & Yr3V & 2 & 3 & 2 & 2 & 2 & 2 & 0 & 1 & 2 & 3 & 1 \\
\hline Moro & Yr10 & 2 & 3 & 0 & 4 & 3 & 2 & 0 & 2 & 0 & 3 & 1 \\
\hline Strubs Dikkopf & YrSd & 2 & 3 & 1 & 3 & 3 & 7 & 1 & 0 & 6 & 7 & 1 \\
\hline Suwon 92m/Omar & YrSu & 2 & 2 & 1 & 3 & 3 & 3 & 0 & 0 & 1 & 6 & 6 \\
\hline Clement & Yr2, Yr9+ & 3 & 3 & 2 & 2 & 2 & 2 & 0 & 1 & 2 & 2 & 0 \\
\hline \multicolumn{13}{|c|}{ European differentials set } \\
\hline Hybrid 46 & Yr4 & 2 & 1 & 0 & 1 & 1 & 0 & 1 & 1 & 1 & 0 & 0 \\
\hline Reichersberg 42 & Yr7+ & 8 & 1 & 1 & 1 & 8 & 7 & 1 & 8 & 7 & 8 & 6 \\
\hline Heines Peko & Yr2, Yr6+ & 8 & 6 & 1 & 7 & 8 & 8 & 2 & 0 & 7 & 7 & 2 \\
\hline Nord Desprez & Yr3N & 2 & 7 & 0 & 4 & 7 & 6 & 4 & 2 & 2 & 4 & 2 \\
\hline Compair & Yr8 & 3 & 3 & 0 & 8 & 7 & 8 & 2 & 6 & 2 & 1 & 1 \\
\hline Carstens V & Yr32+ & 2 & 7 & 2 & 2 & 2 & 2 & 1 & 1 & 2 & 3 & 0 \\
\hline Spalding prolific & YrSp & 1 & 3 & 4 & 0 & 1 & 0 & 2 & 1 & 0 & 0 & 0 \\
\hline Heines VII & Yr2+ & 7 & 1 & 8 & 7 & 6 & 8 & 2 & 1 & 0 & 9 & 8 \\
\hline \multicolumn{13}{|c|}{ Supplemental differential cultivars } \\
\hline Federation*4/Kavkaz & Yr9 & 7 & 8 & 8 & 8 & 9 & 8 & 7 & 7 & 7 & 9 & 9 \\
\hline Anza & Yr18, YrA & 8 & 8 & 8 & 9 & 9 & 9 & 9 & 7 & 8 & 9 & 8 \\
\hline Avocet ' R' & YrA & 8 & 9 & 8 & 9 & 8 & 7 & 9 & 6 & 8 & 9 & 6 \\
\hline Kalyansona & Yr2 & 9 & 6 & 7 & 9 & 7 & 8 & 8 & 9 & 9 & 7 & 6 \\
\hline T. spelta. var. album & Yr5 & 0 & 1 & 1 & 2 & 1 & 1 & 1 & 1 & 0 & 1 & 1 \\
\hline TP1295 & Yr25 & 9 & 8 & 6 & 7 & 7 & 8 & 8 & 8 & 6 & 7 & 7 \\
\hline Federation & Yr17 & 9 & 8 & 8 & 7 & 7 & 7 & 8 & 9 & 9 & 7 & 7 \\
\hline
\end{tabular}

${ }^{\star} Y r=$ yellow rust resistance genes; ${ }^{* *}$ Physiologic races identified in Khuzestan province; ${ }^{* \star \star D i s e a s e}$ reaction scale 0 to 9. 
The selected lines were exposed in trap nurseries to natural yellow rust infection in Ahvaz, Dezful, Shoushtar, Abadan, Masjedsoleyman, Eze, Mahshar and Behbehan during the same period of the study. One single isolate was tested from each sample and analyzed for race identification. According to the results, virulence on Heines Kolben (with genes Yr2 and Yr6), Kalyansona (Yr2), Lee (Yr7), Avocet R (YrA), Federation* 4/Kavkaz (Yr9), TP1295 (Yr25) and Nord despres (Yr3N) was common during the period of investigation (Table 6).

Virulence for Yr1 which is common in Central Asia and China (Anmin et al., 2004), and in most of the Middle East and in north-western Europe were absent in Iran (Afshari et al., 2004; Hovmoller et al., 2007). No virulence was observed on plants with Yr1, Yr3V, Yr4, Yr5, Yr10, Yr25, Yr32+, YrSP and YrSD genes in the trap nurseries. The virulence frequency for the Yr2, Yr6 genes were between 8-16 with a moderately susceptible reaction in Heines peko when for Yr2 in Heines Kolben was calculated to be 100 (Table 5). The frequency of virulence factors to $\mathrm{Yr}$ resistance genes (Table 6) was determined based on infection of resistant cultivars under field conditions in Iran. The frequency of virulence factors in the yellow rust population on the differential genotypes tested in the trap nurseries were above $91 \%$ for the resistance genes Yr2, Yr6, Yr7, Yr2, Yr6+, Yr18,YrA, Yr2, Yr17, Yr25 and YrA however, virulence frequencies for $Y r 7+$ and $Y r 8$ were less than $10 \%$. frequency of virulence factors to all other lines were between 25 and $70 \%$ (Table 6).

Rabaninasab et al., (2008) noted that virulence wasn't detected for plants with genes Yr1, Yr4, Yr5 and Yr10 and virulence on plants with genes Yr2, Yr6, Yr7, Yr9, Yr22, Yr23 and YrA was common in Iran. For instance, virulence to Yr2, Yr6, Yr7 and Yr9 occur in most wheat producing areas of the world (Chen et al. 2002). In Pakestan virulence has been reported to Yr genes Yr2, Yr3, Yr4, Yr6, Yr7, Yr8, Yr9, Yr17, YrCv, YrSu and YrSd (Sumaira, 2009). Yr1, Yr5, YrCv, Yr7, Yr17 and YrSp stripe rust resistance genes were found effective against all isolates collected across the major wheat growing regions of Iran. Yr4 showed high resistance against all or most of the yellow rust isolates. The findings were in agreement with the work of Chen (2005), Afsharri (2008) and Chunmei et al. (2008) who reported that virulences to Yr4 gene rarely occur in most wheat producing areas of the world as a rare phenomenon. Of this virulence, pathotypes possessing the combination of virulence for plants with $Y r 7$ and $Y r 9$ were particularly implicated in the epidemics on Falat cultivar in 2003 in Iran, because this combination overcame the resistance of Seri 82 and the many derivatives of that which were widely grown in West Asia and North Africa (WANA), (Elahinia, 2005). Bread wheat cultivars Seri 82, Falat (in Iran), Mexipac (in Syria) and Gereck (in Turkey) were resistant to the stripe rust populations when initially released. Within a few years of release the corresponding stripe rust virulence genes increased and the resistance genes such as $\mathrm{Yr} 9$ associated with the above cultivars, became ineffective (Torabi et al., 1995; Yahyaoui et al., 2004). The composition of $P$. Striiformis populations could change over time and this can be an important consideration for breeding programs.

The most recently deployed resistance genes Yr18 and Yr27 in several bread wheat cultivars cultivated in CWANA are becoming ineffective against stripe rust pathotypes (Singh et al., 2004). Diverse virulence phenotypes of $P$. striiformis exist under natural field conditions, and some virulence types could eventually develop and spread over larger areas in the region. Surveys of pathogen populations and the genetic characterization of virulence genes continue to provide valuable information used to design breeding strategies and prioritize which pathogen species and physiologic races to target. $P$. striiformis populations in Iran are genetically diverse, and differences in virulence have been identified. In this study, we showed that composition of $P$. striiformis populations changed over time, and this can be an important consideration for wheat breeding programs in the region. 
Table 5. Virulence frequencies of Puccinia striiformis f. sp. tritici isolates collected in 2009 and 2010 from Khuzestan provinces of Iran

\begin{tabular}{|c|c|c|c|c|c|c|c|c|}
\hline \multirow{3}{*}{ Yr gene } & \multicolumn{8}{|c|}{ Virulence frequency (\%) } \\
\hline & \multicolumn{2}{|c|}{ Ahvaz } & \multicolumn{2}{|c|}{ Dezful } & \multicolumn{2}{|c|}{ Izeh } & \multicolumn{2}{|c|}{ Behbahan } \\
\hline & 2009 & 2010 & 2009 & 2010 & 2009 & 2010 & 2009 & 2010 \\
\hline$Y r 1$ & 0 & 0 & 0 & 0 & 0 & 0 & 0 & 0 \\
\hline Yr7 & 60 & 70 & 60 & 80 & 80 & 100 & 80 & 100 \\
\hline Yr2, Yr6 & 100 & 100 & 100 & 100 & 100 & 100 & 100 & 100 \\
\hline Yr3V & 0 & 0 & 0 & 0 & 0 & 0 & 0 & 0 \\
\hline Yr10 & 4 & 4 & 8 & 1 & 0 & 0 & 0 & 0 \\
\hline YrSd & 0 & 0 & 2 & 2 & 2 & 1 & 0 & 0 \\
\hline YrSu & 24 & 48 & 8 & 20 & 0 & 0 & 8 & 20 \\
\hline Yr2, Yr9+ & 0 & 0 & 0 & 8 & 1 & 0 & 0 & 0 \\
\hline Yr4 & 0 & 0 & 0 & 1 & 1 & 1 & 0 & 2 \\
\hline Yr7+ & 0 & 0 & 0 & 0 & 0 & 0 & 0 & 0 \\
\hline Yr2, Yr6+ & 12 & 14 & 8 & 20 & 6 & 16 & 12 & 16 \\
\hline Yr3N & 70 & 64 & 64 & 64 & 45 & 8 & 8 & 64 \\
\hline Yr8, Yr18 & 0 & 1 & 2 & 0 & 0 & 0 & 0 & 12 \\
\hline Yr32+ & 0 & 0 & 0 & 2 & 2 & 1 & 0 & 0 \\
\hline YrSp & 0 & 0 & 0 & 1 & 0 & 0 & 0 & 0 \\
\hline Yr2+ & 1 & 0 & 4 & 8 & 8 & 8 & 12 & 20 \\
\hline Yr9 & 60 & 64 & 70 & 80 & 24 & 24 & 40 & 50 \\
\hline Yr18, YrA & 24 & 8 & 24 & 24 & 12 & 8 & 8 & 16 \\
\hline YrA & 100 & 100 & 100 & 100 & 80 & 100 & 100 & 100 \\
\hline Yr2 & 90 & 40 & 40 & 90 & 80 & 90 & 60 & 80 \\
\hline Yr5 & 0 & 0 & 0 & 0 & 0 & 0 & 0 & 0 \\
\hline Yr25 & 90 & 90 & 80 & 90 & 90 & 100 & 100 & 100 \\
\hline Yr17 & 0 & 0 & 0 & 0 & 0 & 0 & 0 & 0 \\
\hline
\end{tabular}


Table 6. Frequencies of virulence factors of wheat strip rust pathogen in Khuzestan province of Iran

\begin{tabular}{lcc}
\hline Differential genotype & Yrgene & $\begin{array}{c}\text { \% of Frequencies of } \\
\text { virulence factors }\end{array}$ \\
\hline Chinese 166 & Yr1 & 0 \\
Lee & Yr7 & 91.1 \\
Heines Kolben & Yr2, Yr6 & 100 \\
Vilmorin 23 & Yr3V & 0 \\
Moro & Yr10 & 0 \\
Strubs Dikkopf & YrSd & 25 \\
Suwon 92m×Omar & YrSu & 0 \\
Clement & Yr2, Yr9+ & 42 \\
Hybrid 46 & Yr4 & 0 \\
Reichersberg 42 & Yr7+ & 8 \\
Heines Peko & Yr2, Yr6+ & 71 \\
Nord Desprez & Yr3N & 37 \\
Compair & Yr8 & 8 \\
Carstens V & Yr32+ & 57 \\
Spalding prolific & YrSp & 0 \\
Heines VII & Yr2+ & 48 \\
Federation*4/Kavkaz & Yr9 & 97 \\
Anza & Yr18, YrA & 100 \\
Avocet ' R ' & YrA & 100 \\
Kalyansona & Yr2 & 100 \\
T. spelta. var. album & Yr5 & 0 \\
TP1295 & Yr25 & 82 \\
Federation & Yr17 & 85 \\
\hline
\end{tabular}

\section{CONCLUSION}

Despite frequent stripe rust epidemics in Khuzestan Province of Iran, there have been not enough studies on the genetic basis of resistant wheat cultivars and the structures of pathogen population. In the present study genetic structure of wheat cultivars and $P$. striiformis population that naturally occur in the major wheat growing regions of Iran were analyzed and results were discussed in the context of wheat breeding to control stripe rust in the country.

Virulence and diversity of the Iranian stripe rust population were studied using differential genotypes with known $Y r$ genes. There were marked differences in the composition of individual sub-populations in the four tested regions of Iran. Out of the 27 physiological races, only nine of them were common in all regions. This regional variation of the pathotypes might indicate that wheat cultivars could have been developed and released for production on a regional basis. Virulent pathotypes have been already observed to most of the $\mathrm{Yr}$ genes used in Iranian wheat cultivars. Thus, searching for new effective sources of 
stripe rust resistance genes is necessary to cope with changes in the host-pathogen interaction.

\section{ACKNOWLEDGEMENTS}

I thank Dr. Kurt J. Leonard from Department of Plant Pathology University of Minnesota St. Paul, USA for his discussions with me and suggestions, and for providing certain materials for the study. Financial support and the provision of facilities from the Islamic Azad University, Shoushtar Branch for this research is gratefully acknowledged.

\section{REFERENCES}

Afshari, F. (2008). Prevalent pathotypes of Puccinia striiformis f. sp. tritici in Iran. J. Agric. Sci. Technol., 10, 67-78.

Afzal, S.N., Haque, M.I., Ahmedani, M.S., Bashir, S., Rattu, A. R. (2007). Assessment of Yield losses caused by Puccinia striiformis triggering stripe rust in the most cominon wheat varieties. Pak. J. bot., 39, 2127-2134.

Agrios, J.N. (1997). Plant Pathology. 4th Edition. Academic Press Inc., San Diego, CA, USA.

Aime, M.C. (2006). Toward resolving family-level relationships in rust fungi (Uredinales). Mycoscience, 47,112-122.

Bamdadian, A. (1984). Variation in pathogenicity and evolution of Puccinia striiformis West in Iran during 1980-84. In: Proc. European Mediterranean Cereal Rusts Conference, pp. 219-22

Bamdadian, A. (1972). Physiological races of Puccinia striiformis in Iran. Proceeding of the European and Mediterranean Cereal Rust Conference. Prague, pp. 91- 95.

Chen, X.M. (2005). Epidemiology and control of stripe rust (Puccinia striiformis f. sp. triticl) on wheat. Can. J. Plant Pathol., 27, 314-337.

Chen, X.M., Moore, M., Milus, E.A., Long. D.L., Line, R.F., Marshall, D., Jackson, L. (2002). Wheat stripe rust epidemics and races of Puccinia striiformis f. sp. tritici in the United States in 2000. Plant Dis. 86, 39-46.

Chunmei, W., Yiping, Z., Dejun, H., Zhensheng, K., Guiping, L., Aizhong, C. Peidu, C. (2008). SSR and STS markers for wheat stripe rust resistance gene Yr26. Euphytica 158, 359-366.

Elahinia, S.A., Tewari, J.P. (2005). Assessment of Two Different Sources of Durable Resistance and Susceptible Cultivar of Wheat to Stripe Rust (Puccinia striiformis f. sp. tritici). Caspian J. Env. Sci., 3(2), 117-122

Elahinia, S.A. (2000). Assessment of uredinio-spore germination of Puccinia striiformis at various temperature on agar and detached leaves of wheat. Journal of Agriculture, Science and Technology., 2, 1-8.

Elahinia, S.A. (1989). Resistance of Wheat to Puccinia striiformis. Ph.D. Thesis, Univer-sity of Salford, Manchester, UK.

Elyasi-Gomari, S., Lesovaya, G.M. (2009). Harmfulness of wheat leaf rust in Eastern part of forest-steppe of Ukraine. Archives of Phytopathology And Plant Protection, 42(07), $659-665$.

Esfandiari, E. (1947). Cereal rusts in Iran. Journal of Entomology and phytopathology, Plant Pests and Diseases Research Institute, Iran, 4, 67-76 (In Persian).

Johnson, R., Stubbs, R.W., Fuchs, E., Chamberlain, N.H. (1972). Nomenclature for Physiologic Races of Puccinia striiformis infecting Wheat. Trans. Brit. Mycolog. Soil, $58,475-480$. 
Kavak, H. (2009). Epidemic out breaks of stripe rust caused by Puccinia striiformis on natural population of Lolium perenne in Turkey. Pak. J. Bot., 41, 2003-2008.

Khalilzadeh, G.H., Vahabzadeh, R., Ghasemi, M.M., Gharib, E.A. (2008). Study of grain yield, yield components and reactions to yellow rust and fusarium head blight diseases in the promising bread wheat lines in Moghan region. Iranian J. Crop Sci., 10(1), 6071.

Khazra, M.H., Bamdadian, A. (1974). The wheat disease situation in Iran. Proceeding of Fourth FAO/Rockfller Foundation Wheat Seminar, Tehran. Iran, pp. 292- 299.

McNeal, F.H., Konzak, C.F., Smith, E.P., Tate, W.S., Russell, T.S. (1971). A Uniform System for Recording and Processing Cereal Research Data. United States, Department of Agricultural Research Services, ARS, pp. 34-121.

Kolmer, J.A. (1997). Virulence in Puccinia recondita f. sp. tritici isolates from Canada to genes for adult-plant resistance to wheat leaf rust. Plant Dis., 81, 267-271.

Line, R.F., Chen, X.M. (1995). Successes in breeding for and managing durable resistance to wheat rusts. Plant Dis., 79, 1254-1255.

Morgounov, A., Yessimbekova, M.S., Rsaliev, S., Baboev, H., Mumindjanove, E., Djunusova, M. (2004). High yielding winter wheat varieties resistant to yellow and leaf rust in central and Asia. Proceedings of the 11th International Cereal Rusts and Powdery Mildew Conference, Aug. 22-27 johan Innes Centre, Norwich, pp, 52-52.

Nazari, K. (1998). Evaluation of resisitance in bread wheat cultivars and advanced lines to wheat yellow rust at seedling and adult-plant stage and possible postulation of genotypes by gene for gene hypothesis. M.Sc. thesis. Tabriz University. (In Persian)

Okhovat, S.M. (1999). Cereal Diseases. Tehran University, Tehran, Iran.

Peterson, R.F., Campbell, A.B.,Hannah, A.E. (1948). A Diagrammatic Scale for Estimating Rust Intensity of Leaves and Stems of Cereals. Can. J. Res., 26, 496-500.

Rabaninasab, H.A., Okhovat, M., Torabi, M., Abbasi, M., Mozafari, J. (2008). Virulance and Molecular diversity in Puccinia striiformis f. $\mathrm{sp}$. tritici from Iran. Journal of Plant Protection, 22(2), 47-60.

Röbbelen, G., Sharp, E.L. (1978). Mode of inheritance, interaction and application of genes conditioning resistance to yellow rust. Fortschr. Pflanzenzücht, 9, 1-88.

Singh, R.P., Duveiller, E., Huerta-Espino, J. (2004). Virulence to Yellow Rust Resistance Gene Yr27: A New Threat to Stable Wheat Productions in Asia. In 2nd Regional Yellow Rust Conference for Central and West Asia and North Africa, 22-26 March, Islamabad, Pakistan. CARDA, pp. 16-17.

Stubbs, R.W. (1985). Stripe Rust. The Cereal Rusts, Diseases, Distribution, Epidemiology, and control (eds. A. P. Roelf and W.R. Bushnell). Vol. II. PP 61-101. Academic Press. New York

Sumera, R. (2009). Evaluation of Genetic Diversity of Wheat for Stripe Rust (Caused by Puccinia striiformis tritici) Resistance. PhD thesis, Quaid-i-Azam University, Islamabad.

Torabi, M., Nazari, K. (1998). Seedling and adult plant resistance to yellow rust in Iranian bread wheats. Euphytica, 100, 51-54.

Torabi, M., Mardouchi, W., Nazari, K., Golzar, H., Kashani, A.S. (1995). Effectiveness of wheat Yellow Rust Resistance Gene in Different Part of Iran. Cereal Rust and Powdery Mildew Bull., 23, 9-12.

Wan, A., Zhao, Z., Chen, X., He, Z., Jin, S., Jia, Q., Yao, G., Yang, J., Wang, B., Li, G., Bi, Y., Yuan, Z. (2004). Wheat stripe rust epidemic and virulence of Puccinia striiformis $\mathrm{f}$. sp. tritici in China in 2002. Plant Dis., 88, 896-904. 
Wiese, M.V. (1987). Compendium of Wheat Diseases. APS Press, St. Paul, MN, USA. Yahyaoui, A., Singh, R.P., Wellings, C.R. (2004). Yellow Rust in CWANA: Status, Approaches, and Management. Second Regional Yellow Rust Conference for Central and West Asia and North Africa. 22-26 March, Islamabad, Pakistan. ICARDA, p.18.

Zadoks, J.C., Chang, T.T., Konzak, C.F. (1974). A decimal code for the growth stages of cereals. Weed Res., 14, 415-421.

(c) 2011Elyasi-Gomari \& Petrenkova; This is an Open Access article distributed under the terms of the Creative Commons Attribution License (http://creativecommons.org/licenses/by/3.0), which permits unrestricted use, distribution, and reproduction in any medium, provided the original work is properly cited. 